Канд. техн. наук А.В. Труфанова

Cand. of techn. sciences A.V. Trufanova

\title{
КОНТРОЛЬ І ОЦІНКА ЯКОСТІ ІСНУЮЧИХ КОНСТРУКЦІЙ БУКСОВИХ ПІДШИПНИКОВИХ ВУЗЛІВ ЗА ДОПОМОГОЮ МОРФОЛОГІЧНОГО АНАЛІЗУ
}

\section{QUALITY CONTROL AND EVALUATION OF EXISTING STRUCTURES AXLEBOX ASSEMBLY USING MORPHOLOGICAL ANALYSIS}

\section{Представив д-р техн. наук, професор І.Е. Мартинов}

\begin{abstract}
Постановка проблеми.Переважна більшість загального вантажообігу i більша частина пасажирообороту у народному господарстві України виконується залізничним транспортом. Виконати такий обсяг перевезень можливо тільки при задовільному технічному стані рухомого складу залізниць України.

Робочий парк вантажних вагонів України, що належить Державній адміністрації залізничного транспорту України (УЗ), складає близько 100 тис. вагонів. Але за часів незалежності оновлення вагонного парку майже не проводилось. Це призвело до того, що середній вік вагонів перевищив 20 років, а ïx технічний стан погіршується. Про це свідчить велика кількість відчеплень вагонів у поточний неплановий ремонт[1]. Значна частка цих відчеплень викликана відмовами буксових вузлів (БВ).
\end{abstract}

Безумовно, підвищення експлуатаційної надійності рухомого складу залежить від надійної роботи буксових вузлів вагонів. Одним із шляхів вирішення цього завдання $\epsilon$ оптимізація різних конструкцій буксових вузлів 3 наступним контролем i оцінкою якості буксових підшипників.

Мета дослідження. Найбільш важливим елементом буксового вузла вагона з точки зору забезпечення безпеки руху є підшипник.

Саме відмови підшипників спричиняють переважну більшість відмов буксового вузла в цілому [5-7], тому необхідно визначити технікоексплуатаційні критерії оцінки варіантів конструкції буксового вузла. Для цього доцільно використовувати метод морфологічного аналізу, сутність якого полягає у пошуці найкоротшого шляху 
вирішення технічного завдання або об'єкта шляхом оптимального вибору варіантів конструкцій.

Основна частина (результати експериментального дослідження). Будьякий буксовий вузол складається 3 таких елементів:

- комплект 3 двох підшипників (або один підшипник підвищеної вантажопідйомності);

- ущільнення, які призначені для запобігання потраплянню бруду та вологи в робочу зону підшипників;

- торцеве кріплення підшипників,яке обмежує пересування підшипників уздовж шийки осі;

- корпус букси (або інший пристрій, що його замінюе) 3 приливами та посадочними місцями для кріплення елементів, призначених для передачі навантажень та зв'язку колісної пари 3 рамою візка.

Також букси вагонів можна класифікувати за різними ознаками [2]:

- за типом вагона - букси пасажирських та вантажних вагонів;

- за способом посадки внутрішнього кільця підшипника на шийку осі -3 гарячою, втулковою та пресовою посадками;

- за типом торцевого кріплення підшипника на шийці осі - 3 кріпленням гайкою або шайбою;

- за числом підшипників - 3 одним або двома роликовими підшипниками, крім того, 3 додатковим упорним кульковим підшипником;

- за наявністю корпусу букси корпусні та безкорпусні.

В інженерній практиці зазвичай не існує способів, що дозволяють за умови наявності технічного завдання одразу ж вибрати оптимальну структуру пристрою. В результаті процес розроблення носить інтерактивний характер. Зазвичай розробник визначає, до якого класу пристрою може належати проектована модель, а потім звузити цей клас за допомогою випробувань до декількох технічних рішень, які належать цьому класу, і вибрати найбільш оптимальне.

Морфологічний аналіз і синтез технічних рішень заснований на евристичному підході [8]. За допомогою цього методу можливо досліджувати об'єкт iз системних позицій i здійснювати спрямований підбір можливих варіантів рішень, а також відкинути свідомо непотрібні об'єкти та до мінімуму зменшити число варіантів, які можуть зазнавати техніко-економічного порівняння.

Оптимізація буксових вузлів [3,4] вантажних вагонів здійснювалась в такій послідовності: спочатку за вказаним критерієм 3 технічно обгрунтованих конструкцій проводився відбір декількох основних варіантів, потім за допомогою техніко-економічного порівняння обирався найбільш раціональний варіант конструкцій буксового вузла, який би міг повністю здійснювати зв'язок між рамою візка й колісною парою, а також забезпечував надійність експлуатації вантажних вагонів.

На етапі аналітичної обробки даних за допомогою морфологічної таблиці здійснювались арифметичні обчислення, включаючи порівняльний та факторний аналіз.

При використанні морфологічної таблиці (табл. 1) забезпечувалось зменшення обсягу вихідних даних аналітичного запису, систематизація та виявлення закономірностей, а також видно повну наочність дослідження. Сукупність аналізованих значень упорядковувалась за принципом від кращого варіанта до гіршого. Кращому значенню присвоювалося перше місце, наступному друге i т.п. Отримані місця підсумовувались та кращим варіантом ставав той варіант конструкції буксових вузлів, який набере найменше значення (табл. 2). 
Таблиця 1

Порівняно-факторний аналіз конструкцій буксових вузлів

\begin{tabular}{|c|c|c|c|c|c|}
\hline $\begin{array}{c}\text { Тип } \\
\text { підшипника }\end{array}$ & $\begin{array}{l}\text { Особливості } \\
\text { конструкції }\end{array}$ & $\begin{array}{c}\text { Посадка } \\
\text { підшипника } \\
\text { на вісь } \\
\end{array}$ & $\begin{array}{c}\text { Торцеве } \\
\text { кріплення }\end{array}$ & Переваги & Недоліки \\
\hline Циліндричні & $\begin{array}{c}\text { Поліамідний } \\
\text { сепаратор }\end{array}$ & Теплова & & $\begin{array}{l}\text { - підвищена надійність; } \\
\text { - ліквідація витрат кольорових } \\
\text { металів }\end{array}$ & $\begin{array}{l}\text { - необхідність правильного } \\
\text { підбору радіальних та } \\
\text { осьових зазорів; } \\
\text { - радіальні сили } \\
\text { сприймаються в режимі } \\
\text { тертя кочення роликів по } \\
\text { доріжках кочення кілець; } \\
\text { - осьові в режимі тертя } \\
\text { ковзання торців роликів об } \\
\text { спрямовуючі борти кілець; } \\
\text { - невизначеність з фактич- } \\
\text { ним ресурсом сепаратора }\end{array}$ \\
\hline $\begin{array}{l}\text { Два цилін- } \\
\text { дричні та } \\
\text { один } \\
\text { кульковий }\end{array}$ & $\begin{array}{c}\text { Кульковий } \\
\text { підшипник } \\
\text { розташований } \\
\text { між } \\
\text { роликовим. } \\
\text { Зменшена } \\
\text { довжина } \\
\text { роликів. }\end{array}$ & Теплова & \multirow[t]{2}{*}{  } & $\begin{array}{l}\text { - підвищена надійність за рахунок } \\
\text { повного сприйняття кульковим } \\
\text { підшипником осьових навантажень та } \\
\text { визволення роликів від сприйняття } \\
\text { осьових сил }\end{array}$ & $\begin{array}{l}\text { - ускладнена конструкція; } \\
\text { - підвищена трудомісткість } \\
\text { проведення монтажно- } \\
\text { демонтажних робіт }\end{array}$ \\
\hline $\begin{array}{l}\text { Дворядний } \\
\text { конічний }\end{array}$ & $\begin{array}{l}\text { Не касетного } \\
\text { типу. }\end{array}$ & Пресова & & $\begin{array}{l}\text { - сприйняття радіальних та осьових } \\
\text { сил тертям кочення }\end{array}$ & $\begin{array}{l}\text { - необхідність періодичного } \\
\text { регулювання зазорів }\end{array}$ \\
\hline $\begin{array}{l}\text { Дворядний } \\
\text { конічний }\end{array}$ & $\begin{array}{l}\text { Касетного } \\
\text { типу }\end{array}$ & Пресова & Шайба & $\begin{array}{l}\text { - сприйняття радіальних та осьових } \\
\text { сил тертям кочення; } \\
\text { - ліквідація проміжних ревізій букс; } \\
\text { - підвищена надійність, збільшений } \\
\text { ресурс }\end{array}$ & $\begin{array}{l}\text { - висока вартість } \\
\text { підшипникового вузла }\end{array}$ \\
\hline
\end{tabular}


Таблиця 2

Зведення показників оцінки якостей конструкцій буксових вузлів

\begin{tabular}{|c|c|c|c|c|}
\hline \multirow[b]{2}{*}{ Тип підшипника } & \multicolumn{3}{|c|}{ Оцінка якості } & \multirow{2}{*}{$\begin{array}{c}\text { Підсумковий } \\
\text { коефіцієнт }\end{array}$} \\
\hline & $\begin{array}{l}\text { Особливості } \\
\text { конструкції }\end{array}$ & $\begin{array}{c}\text { Посадка } \\
\text { підшипника на вісь }\end{array}$ & $\begin{array}{l}\text { Торцеве } \\
\text { кріплення }\end{array}$ & \\
\hline Кулькові & 9 & 3 & $1-$ & 13 \\
\hline Сферичні & 8 & 3 & 1 & 12 \\
\hline Сферичні & 7 & 3 & 1 & 11 \\
\hline Циліндричні & 6 & 2 & 1 & 9 \\
\hline Циліндричні & 5 & 2 & 1 & 8 \\
\hline $\begin{array}{l}\text { Два циліндричні та } \\
\text { один кульковий }\end{array}$ & 4 & 2 & 1 & 7 \\
\hline $\begin{array}{l}\text { Два циліндричні та } \\
\text { один кульковий }\end{array}$ & 3 & 2 & 1 & 6 \\
\hline Дворядний конічний & 2 & 1 & 1 & 4 \\
\hline Дворядний конічний & 1 & 1 & 1 & 3 \\
\hline
\end{tabular}

В результаті проведеного морфологічного аналізу можна зробити висновки, що в сукупності усіх значень варіантів конструкцій буксових вузлів найбільш низькі бали отримала конструктивна схема буксового вузла 3 дворядними конічними підшипниками. Така конструкція має принципові переваги саме в БВ вантажних вагонів. Буксові вузли 3 дворядними конічними підшипниками касетного типу сприймають осьові зусилля торцевими частинами роликів 3 тертям ковзання.

\section{Висновки:}

1. Буксові вузли вантажних вагонів $€$ одними 3 найважливіших елементів ходових частин вантажних вагонів. Ї̈ безвідмовна робота впливає на безпеку руху. Основною особливістю існуючих БВ вантажних вагонів $\epsilon$ використання циліндричних роликових підшипників. Але такі БВ за останні роки експлуатації показали свою недостатню надійність. На залізницях почастішали випадки надмірного нагріву БВ через відмову ї різних елементів. В той же час на залізницях інших країн 3 успіхом використовуються інші конструктивні схеми буксових вузлів.

2. Проведено морфологічний аналіз конструкцій буксових підшипникових вузлів вантажних вагонів i визначені їх переваги та недоліки. В результаті можна зробити висновки, що в сукупності усіх значень варіантів конструкцій буксових вузлів найбільш низькі бали отримала конструктивна схема буксового вузла 3 дворядними конічними підшипниками. Така конструкція має принципові переваги саме в БВ вантажних вагонів. Буксові вузли 3 дворядними конічними підшипниками касетного типу сприймають осьові зусилля торцевими частинами роликів 3 тертям ковзання.

3. Показано, що переважна більшість досліджень спрямована на поліпшення конструктивних особливостей існуючого варіанта БВ з циліндричними роликовими підшипниками. Але, як правило, ці роботи виконувались емпіричним шляхом. Спостерігається дефіцит теоретичних досліджень в галузі підвищення надійності та працездатності БВ. 


\section{Сиисок літератури}

1. Протокол наради при заступнику Генерального директора Укрзалізниці Лашко А.Д. від 08.10.2002 [Текст]. - К.: Укрзалізниця, 2002. - 2 с.

2. Конструирование и расчёт вагонов [Текст]: учеб. для вузов ж.-д. трансп. / В.В. Лукин, Л.А. Шадур, В.Н. Котуранов [и др.]. - М.: УМК МПС России, 2000. - 731 с.

3. Чебаненко, В.М. К вопросу выбора рациональной конструкции вагонной роликовой буксы [Текст] / В.М. Чебаненко // Техника железнодорожных дорог. - 1952. - №7. - С. 11-16.

4. Перов, С.В. Совершенствование конструкции вагонных букс с подшипниками качения [Текст]: дис. ... канд. техн. наук: 05.22.07 / Перов Сергей Викторович. - М., 1988. $316 \mathrm{c}$.

5. Мартинов, I.Е. Технічний стан буксових роликопідшипників вантажних вагонів [Текст] / I.Е. Мартинов // Зб. наук. праць. - Харків: ХарДАЗТ, 2000. - Вип. 41. - С. 38-42.

6. Мартынов, И.Э. Анализ опыта эксплуатации цилиндрических роликоподшипников букс грузовых вагонов [Текст] / И.Э. Мартынов // Вісник Східноукраїнського державного університету. - Луганськ, 2000. - №5 (27). - С. 157-159.

7. Цюренко, В.Н. Опыт эксплуатации вагонов с буксовыми узлами на подшипниках качения [Текст] / В.Н. Цюренко // Пути совершенствования конструкций буксовых узлов вагонов с подшипниками качения: Труды ВНИИЖТ. - М.: Транспорт, 1982. - Вып. 654. C. 4-26.

8. Половинкин, А.И. Основы инженерного творчества [Текст]: пособ. для студентов высших техн. учеб. заведений / А.И. Половинкин. - М.: Машиностроение, 1988. - 368 с.

Ключові слова: буксовий вузол (БВ), підшипник, оптимізація, об'єкти, аналіз, синтез, корпусні, безкорпусні.

\section{Анотації}

Проведено морфологічний аналіз конструкцій буксових підшипникових вузлів вантажних вагонів, виконані арифметичні обчислення, включаючи порівняльний та факторний аналіз.Показано, що буксові вузли 3 дворядними конічними підшипниками вантажних вагонів мають принципові переваги. Така конструкція сприймає осьові зусилля торцевими частинами роликів з тертям ковзання.

Проведен морфологический анализ буксовых подшипниковых узлов грузовых вагонов, выполнены арифметические вычисления, включая сравнительный и факторный анализ. Показано, что буксовые узлы с двухрядными коническими подшипниками грузовых вагонов имеют принципиальные преимущества. Такая конструкция воспринимает осевые усилия торцевыми частями роликов с трением скольжения.

Morphological analysis of the axlebox bearing uz-fishing of freight cars, performed arithmetic, including comparative and factorial analysis. It is shown that буксовые nodes with double-row tapered roller bearings of freight cars have major advantages. This design accommodates axial forces end sections clips from the friction of sliding. 